\title{
ТОЛЕРАНТНІСТЬ ЯК СИСТЕМНА ХАРАКТЕРИСТИКА ОСОБИСТОСТІ СТУДЕНТА
}

\begin{abstract}
Долгопол О. О.
кандидат педагогічних наук, ст. викладач, Харківський національний університет міського господарства імені О. М. Бекетова, м. Харків, Україна

Клюєва А. С.

здобувач першого (бакалаврського) рівня вищої освіти, Харківський національний університет міського господарства імені О. М. Бекетова,

м. Харків, Україна
\end{abstract}

Висвітлено результати проведеного дослідження щуодо визначення сучасними студентами поняття «толерантність». 3'ясовано, що студенти розуміють толерантність як вміння підтримувати доброзичливі стосунки з оточуючими не залежно від вікових, релігійних, гендерних, професійних та інших відмінностей.

Ключові слова: особистість, толерантність, емпатія, студентський колектив, сучасна молодь.

The results of the research on the definition of the concept of tolerance by modern students are highlighted. It is found that students consider tolerance to be an ability to maintain friendly relations with others regardless of age, religion, gender, professional and other differences.

Key words: personality, tolerance, empathy, student group, modern youth.

Риси XXI століття (мультикультуралізм, глобалізаційні процеси, інформаційно-комунікаційні технології, індивідуалізація людини) позначаються на студентському колективі. Він є динамічним явищем, яке відображає зміни у свідомості молоді, взагалі. Багато представників покоління Z, народженого в період 1997-2010 pp. (Generation Z, або в розмовній мові — «зумери») наразі навчаються у закладах вищої освіти. Їх вирізняють прогресивні погляди на різноманітні питання: від гендерних, етичних, освітянських до підприємницьких. У цьому контексті набуває актуальності розуміння значення поняття «толерантність» представниками студентського колективу, вивчення іiі проявів у повсякденному житті молоді.

Особистість студента постійно перебуває у полі наукових інтересів психологів, педагогів, культурологів, соціологів. Студент - уже до- 
статньою сформована особистість із закріпленими переконаннями та мотивами у побудові стосунків, поведінці, діяльності. Він активний у суспільному житті, відкритий до змін, що відбуваються в усіх його сферах. Психологів цікавить, як студент ставиться до інших, як сприймає «інакшість», як організовує комунікацію на тлі розмаїття релігійних, культурних, ідеологічних переконань.

Метою дослідження є 3'ясувати суть поняття «толерантність», узагальнити розуміння толерантності студентським колективом.

Методи дослідження: аналіз наукових джерел з проблеми, бесіда, анкетування за відповідними методиками, математична обробка отриманих даних.

Аналіз наукових джерел $[1,4,5]$ дає підстави визначити толерантність як системну характеристику особистості, що має рівневу структуру детермінації: психофізіологічний, індивідуально-психологічний і соціально-психологічний рівні. Толерантність на соціально-психологічному рівні розуміють як прийняття [4, с.88], на індивідуально-психологічному рівні - як поблажливість (толерантність) [2, с. 24], на психофізіологічному - як витривалість [3, с. 418]. Для досягнення мети дослідження було проведено бесіди та анкетування за зазначеними нижче методиками. Вибір методик дослідження пов'язаний із визначенням поняття толерантності, яке розуміємо як стійку позицію особистості щодо особистісних установок, цінностей і змістів, вони $\epsilon$ мотиваційно регулюючими корелятами, що визначають реальну поведінку особистості.

В. Павленко, М. Мельничук виокремлюють в понятті «толерантність» тріаду компонентів: когнітивний, емоційний і поведінковий [2, с. 112]. За розробленим науковцями психодіагностичним комплексом для вивчення особливостей толерантності як системної характеристики особистості до діагностики було залучено 78 студентів, які вивчають вибіркову дисципліну «Психологія» у Харківському національному університеті міського господарства імені О. М. Бекетова. На соціально-психологічному рівні використано методику Ш. Шварца «Вивчення цінностей особистості»; на індивідуально-психологічному рівні — «Тест дивергентного (творчого) мислення Ф. Вільямса» (когнітивний компонент); «Опитувальник для діагностики здібності до емпатії (за А. Мехрабіаном, Н. Епштейном)» та методику Н. Холла на визначення рівня емоційного інтелекту (емоційний компонент); мето- 
дику дослідження малюнкової фрустрації (за С. Розенцвейгом) (поведінковий компонент); на психофізіологічному рівні - експрес-опитувальник «Індекс толерантності» (автори Г. Солдатова, О. Кравцова, О. Хухлаєв, Л. Шайгерова); методику діагностики загальної комунікативної толерантності (за В. В. Бойко) (толерантність) [6].

За методикою, розробленою Г. Солдатовою, О. Кравцовою, О. Хухлаєвим та Л. Шайгеровою «Індекс толерантності» з'ясовано рівень етнічної та соціальної толерантності, толерантності як риси особистості, загальний рівень толерантності. Отримали середній показник більше 115 балів, що свідчить про доволі високий рівень толерантності. Однак, у відповідях приблизно 10\% респондентів простежується тенденція до потурання, поблажливості та в деяких випадках байдужності.

За методикою діагностики загальної комунікативної толерантності (В. Бойко) перевірено рівень загальної комунікативної толерантності. Отримали такі результати: за шкалою 1 «Неприйняття або нерозуміння індивідуальності іншої людини» - високий ступінь нетерпимості респондентів до оточуючих продемонстрували близько 24 \%; за шкалою 2 «Використання себе як еталона при оцінці поведінки й напряму думок інших людей» 16 \% респондентів показали високий рівень; за шкалою 3 «Категоричність або консерватизм в оцінках інших людей» маємо низький рівень нетерпимості (близько 6 \%); за шкалою 5 «Прагнення переробити, перевиховати партнерів» так само отримано низький рівень (8 \%); показники, отримані за шкалою 7 «Невміння вибачати іншим помилки, незручність, ненавмисно заподіяні вам неприємності» (32 \%) говорять про високий рівень нетерпимості респондентів; натомість за шкалою 8 «Нетерпимість до фізичного або психічного дискомфорту, створюваному іншими людьми» студенти продемонстрували середній рівень терпимості (16\%).

Промовисті результати отримано під час аналізу відповідей за методикою для діагностики здібності до емпатії (за А. Мехрабіаном, Н. Епштейном). Метою дослідження було виявлення рівня емпатичної тенденції студентів. Маючи середні (авторські) значення за методикою, після обробки відповідей респондентів отримано такі результати: дівчата продемонстрували вищий, ніж у хлопців, рівень емпатичних тенденцій, що пояснюємо вищим ступенем чуйності у жіночої статі і більшої стриманості у чоловічої. 
Аналіз частини дослідження, проведеної за методикою визначення рівня емоційного інтелекту (за Н. Холом) показав середній рівень (показники 8-13) здатності розуміти відносини особистості, які репрезентуються в емоціях та керувати емоційною сферою на основі прийняття рішень.

Отже, толерантність у широкому розумінні усвідомлюється студентами як вміння підтримувати доброзичливі стосунки з оточуючими, як позитивне ставлення до інших людей незалежно від вікових, релігійних, гендерних, професійних та інших відмінностей. Емпатія один із найчастіших проявів толерантності студентів.

\section{Список використаних джерел:}

1. Іванцев Н. І. Динаміка ціннісних орієнтацій студентської молоді протягом професійної підготовки : автореф. дис... канд. психол. наук : 19.00.07. Київ, 2001. 19 с.

2. Павленко В. М., Мельничук М. М. Психологія толерантності особистості (на матеріалі дослідження студентів) : монографія. Полтава : ФОП Мирон I. А., 2014. 244 с.

3. Психологічна енциклопедія / авт.-упоряд. О. М. Степанов. Київ : Академвидав, 2006. 424 с.

4. Романчук О. Соціальна толерантність як фактор суспільної свідомості (проблеми формування в сучасному ринковому середовищі). Вища школа. 2004. №1. С. 87-91.

5. Скрипченко О. Толерантність як морально-психологічне явище. Молодь, освіта, наука, культура і національна свідомість: зб. матер. Всеукр. наук.практ. конф. (Київ, 27-28 берез. 2003 р.): у 5-ти т. Київ : Вид-во Свропейського ун-ту, 2003. Т. 2. 356 с. С. 287-290.

6. Психодиагностика толерантности личности / под ред. Г. У. Солдатовой, Л. А. Шайгеровой. Москва : Смысл, 2008. 172 с. 